\title{
PENENTUAN CABANG USAHATANI PADI, JAGUNG, DAN KEDELAI YANG OPTIMUM MELALUI POLA DIVERSIFIKASI DENGAN PENDEKATAN LINEAR PROGRAMMING DI KABUPATEN MUARO JAMBI
}

\author{
Yusma Damayanti", Riri Oktari Ulma \\ Program Studi Agribisnis, Fakultas Pertanian, Universitas Jambi \\ J1. Lintas Sumatera Jl. Jambi - Muara Bulian No.Km. 15, Mendalo Darat, Jambi Luar Kota, \\ Kabupaten Muaro Jambi, Jambi 36122 \\ *Corresponding author: ryryady.ulma@yahoo.com
}

\begin{abstract}
This study aims to: (1) establish an approach to determine the optimum scale of rice, corn, and soybean that can be managed by farmers according to their limitations, (2) to find out whether rice, corn, and soybean that optimum are cultivated by farmers, (2) to know and analyze cropping pattern that provide maximum income. This research was conducted in Petanang and Sungai Aur Village, Kumpeh District, Muaro Jambi Regency. The sample farmers in this research are 56 farmers who do farming with pajale system (rice, corn, and soybean). The analytical method used is descriptive and quantitative analysis. The results showed that there were 3 cropping patterns that had the potential to be optimized, namely pattern 1: potential rice, maize and soybeans to be cultivated in MT I, MT II, and MT III of the available land area with a 300\% cropping index covering 4.8 ha, pattern II; rice is cultivated in MT I with a maximum area of 1.6 ha. Whereas potential maize and soybeans are cultivated in MT II and III of the available land area with a 200\% cropping index covering 3.2 ha. - Cropping pattern III; rice is cultivated only in MT I, maize in MT II and soybeans in MT III, with a maximum area of 1.6 ha. Rice and corn commodities are considered optimal for development by farmers in the study area. Of the three cropping patterns the most optimal is the cropping pattern I, followed by cropping patterns of models II and III.
\end{abstract}

Keywords: cropping pattern, optimization, rice, corn, soybean

\begin{abstract}
Abstrak: Penelitian ini bertujuan untuk : (1) mengadakan suatu pendekatan untuk menentukan skala optimum tanaman padi, jagung, dan kedelai yang mampu dikelola petani sesuai dengan keterbatasan yang dimilikinya, (2) mengetahui apakah padi, jagung, dan kedelai optimum diusahakan petani, dan (3) mengetahui dan menganalisis pola pertanaman yang memberikan pendapatan maksimum. Penelitian dilakukan di Desa Petanang dan Desa Sungai Aur Kecamatan Kumpeh Kabupaten Muaro Jambi. Petani sampel sebanyak 56 orang yaitu petani yang melakukan usahatani dengan sistem pajale (padi, jagung, dan kedelai). Metode analisis yang digunakan adalah analisis deskriptif dan kuantitatif. Hasil penelitian menunjukkan bahwa terdapat 3 pola tanam yang berpotensi untuk dioptimalkan yaitu pola 1) padi, jagung, dan kedelai potensi untuk diusahakan pada MT I, MT II, dan MT III dari luas lahan tersedia dengan indeks pertanaman $300 \%$ seluas 4,8 ha, pola 2) padi diusahakan pada MT I seluas maksimum 1,6 ha. Sedangkan jagung dan kedelai potensi diusahakan pada MT II dan III dari luas lahan yang tersedia dengan indeks pertanaman $200 \%$ seluas 3,2 ha.- Pola tanam 3) padi diusahakan hanya di MT I, jagung di MT II dan kedelai di MT III, dengan luas masing-masing maksimum sebesar 1,6 ha. Komoditi padi dan jagung dinilai optimal untuk dikembangkan oleh petani di daerah penelitian, Dari ketiga pola tanam tersebut yang paling optimal adalah pola tanam I, kemudian diikuti dengan pola tanam model II dan III.
\end{abstract}

Kata Kunci: cabang usahatani, optimalisasi, padi, jagung, kedelai 


\section{PENDAHULUAN}

Tanaman pangan merupakan salah satu sub sektor pertanian yang menjadi prioritas untuk dikembangkan, terutama untuk meningkatkan produksi dan pendapatan petani, memelihara kemantapan swasembada pangan, memperbaiki kualitas gizi masyarakat dan memperluas lapangan kerja. Usaha-usaha pokok yang telah ditempuh pemerintah untuk mencapai tujuan tersebut adalah upaya ekstensifikasi, intensifikasi, diversifikasi dan rehabilitasi.

Tanaman pangan yang menjadi sumber makanan pokok bagi sebagian besar penduduk di Indonesia adalah padi, jagung dan kedelai. Kondisi yang demikian menyebabkan tanaman tersebut merupakan tanaman pangan yang banyak dibudidayakan oleh petani di Indonesia, termasuk petani yang ada di Provinsi Jambi. Perkembangan luas panen, produksi dan produktivitas padi (padi sawah), jagung dan kedelai di Provinsi Jambi dapat dilihat pada Tabel 1.

Tabel 1 menunjukan bahwa, luas panen dan produksi padi menunjukan trend yang selalu menurun, dimana luas dan produksi terendah terjadi di tahun 2015.Sementara luas panen dan produksi jagung cenderung meningkat dengan tingkat produktivitas yang terbesar terjadi pada tahun 2015. Sedangkan tanaman kedelai menunjukan luas panen dan produksi yang berfluktuasi.

Dari gambaran pada Tabel 1 dapat dinyatakan bahwa, tanaman jagung merupakan cabang usahatani alternatif yang memiliki potensi paling besar untuk dikembangkan karena tanaman ini mempunyai hasil yang lebih tinggi dibandingkan padi dan kedelai. Namun demikian salah satu teknologi yang tepat bagi pengembangan usahatani tanaman pangan adalah melalui pengunaan faktor produksi yang tepat dan pemilihan teknologi pola pertanaman dengan tumpang gilir sebaik-baiknya.

Tumpang gilir merupakan sistem bercocok tanam pada sebidang lahan yang terdiri dari beberapa kali tanam dari beberapa jenis tanaman secara bergiliran, tumpang sari ataupun bersisipan dengan tujuan untuk meningkatkan produkvitas lahan atau pendapatan petani tiap satuan luas dalam satuan waktu tertentu (Kuntjoro, 1977).

Sejalan dengan pengembangan tanaman pangan melalui pemilihan teknologi pola pertanaman, dewasa ini pemerintah telah mengembangkan program upaya khusus padi, jagung, kedelai yang sering disebut program upsus pajale.Provinsi Jambi merupakan salah tempat dimana dilaksanakannya program tersebut.

Program Upaya Khusus (Upsus) Pajale ini telah dilaksanakan secara menyeluruh di setiap kabupaten yang ada di provinsi Jambi. Kabupaten Muaro Jambi merupakan salah satu kabupaten yang bergabung dalam program upaya khusus pajale dimana dengan program ini diharapkan Kabupaten Muaro Jambi mampu memberikan produksi pada, jagung dan kedelai sesuai dengan target yang diharapkan dan mampu menunjang produksi dan berkontribusi terhadap produk pangan nasional.

Pola tanam padi, jagung dan kedelai yang dilaksanakan petani di Kabupaten Muaro Jambi adalah pola tanam satu musim tanam dalam setahun.

Tabel 1. Perkembangan Luas panen, Produksi dan Produktivitas Padi Sawah, Jagung, dan Kedelai di Provinsi Jambi Tahun 2008-2015.

\begin{tabular}{|c|c|c|c|c|c|c|c|c|c|}
\hline \multirow[b]{2}{*}{ Tahun } & \multicolumn{2}{|l|}{ Padi } & \multicolumn{4}{|c|}{ Jagung } & \multicolumn{3}{|c|}{ Kedelai } \\
\hline & $\begin{array}{r}\text { Luas } \\
\text { Panen } \\
\text { (ha) }\end{array}$ & $\begin{array}{c}\text { Produksi } \\
\text { (Ton) }\end{array}$ & $\begin{array}{c}\text { Produk } \\
\text { tivitas } \\
\text { (Ton/Ha) }\end{array}$ & $\begin{array}{r}\text { Luas } \\
\text { Panen } \\
\text { (ha) }\end{array}$ & $\begin{array}{c}\text { Produksi } \\
\text { (Ton) }\end{array}$ & $\begin{array}{c}\text { Produk } \\
\text { tivitas } \\
\text { (Ton/Ha) }\end{array}$ & $\begin{array}{r}\text { Luas } \\
\text { Panen } \\
\text { (ha) }\end{array}$ & $\begin{array}{c}\text { Produksi } \\
\text { (Ton) }\end{array}$ & $\begin{array}{c}\text { Produk } \\
\text { tivitas } \\
\text { (Ton/Ha) }\end{array}$ \\
\hline 2011 & 132.523 & 570.553 & 4,30 & 6.706 & 25.521 & 3,8 & 4.563 & 5.668 & 1,42 \\
\hline 2012 & 124.443 & 549.779 & 4,18 & 6.587 & 25.571 & 3,82 & 2.809 & 3.516 & 1,52 \\
\hline 2013 & 129.341 & 589.784 & 4,56 & 6.504 & 25.690 & 3,95 & 1.877 & 2.327 & 1,14 \\
\hline 2014 & 121.722 & 587.384 & 4,82 & 7.937 & 43.616 & 5,48 & 5.288 & 6.800 & 1,36 \\
\hline 2015 & 120.207 & 485.989 & 4,75 & 8.486 & 51.712 & 6,09 & 4.906 & 6.732 & 1,38 \\
\hline
\end{tabular}

Sumber : Badan Pusat Statistika Provinsi Jambi tahun 2016 
Tanaman padi ditanam pada musim tanam I (MT I) yaitu di bulan November sampai dengan Febuari (musim hujan). Waktu panen padi adalah 95 hari (3 bulan). Sedangkan jagung ditanam setelah panen padi yaitu pada musim tanam II (MT II) di bulan Maret sampai Juni. Waktu panen jagung adalah 7 sampai 8 minggu. Sementara itu tanaman kedelai ditanam pada bulan Juli sampai Oktober, yaitu pada musim tanam III (MT III) setelah panen jagung berakhir. Adapun luas lahan yang diusahakan petani untuk padi, jagung dan kedelai di Kabupaten Muaro Jambi Kecamatan Kumpeh bervariasi. Petani yang memiliki luas 0,5 - 1 ha lebih banyak jumlahnya dibandingkan petani dengan luas lahan 1,5- 2 ha. (Pini AS, 2018).

Ukuran potensi ekonomi petani dalam mengelola usahataninya dapat diukur dari luas tanah garapannya. Petani dengan garapan yang luas akan memungkinkan untuk memperoleh pendapatan yang lebih tinggi per satuan luas dibandingkan dengan garapan yang lebih sempit. Kondisi demikian membuat mereka mampu menyediakan alat petanian dan modal yang sesuai dengan luas usahanya dan mampu mengupah tenaga kerja. Hal yang sebaliknya dengan petani dengan garapan lebih kecil, yang hanya mengandalkan tenaganya dan tenaga keluarga saja. (Pudjiastuti,1985)

Lahan merupakan sumberdaya pertanian yang sangat penting dalam kegiatan usahatani, hal ini terlihat dari balas jasa yang diterima petani dari lahan tersebut. Kondisi demikian membuat potensi lahan pangan yang tersedia perlu dimanfaatkan dengan pola pertanaman secara optimal agar pendapatan yang maksimum bisa dirasakan oleh petani. Sebagaimana Panggabean (1982) mengemukakan bahwa jika tidak ada pembatas dalam menggunakan sumberdaya tentunya petani akan selalu memperbanyak cabang usahatani ataupun kombinasinya, baik dalam luas, frekuensi maupun variasi usahataninya, karena selalu ada pembatas tertentu maka petani pada umumnya terpaksa hanya mengusahakan beberapa cabang atau beberapa kombinasi usahatani saja dengan skala luas yang tertentu pula.

Penelitian ini bertujuan untuk: (1) mengadakan suatu pendekatan untuk menentukan skala optimum tanaman padi, jagung, dan kedelai yang mampu dikelola petani sesuai dengan keterbatasan yang dimilikinya, (2) mengetahui apakah padi, jagung, dan kedelai optimum diusahakan petani, dan (3) mengetahui dan menganalisis pola pertanaman yang memberikan pendapatan maksimum.

\section{METODE PENELITIAN}

Penelitian ini dilakukan di Desa Petanang dan Desa Sungai Aur Kecamatan Kumpeh Kabupaten Muaro Jambi. Penarikan sampel dalam penelitian ini menggunakan metode purposive sampling dengan pertimbangan bahwa di Kecamatan Kumpeh Kabupaten Muaro Jambi terdapat petani yang berusahatani Pajale (padi sawah, jagung dan kedelai) dan diperoleh sebanyak 56 sampel.

Jenis data yang digunakan dalam penelitian ini adalah data primer dan data sekunder. Data primer diperoleh dari responden berdasarkan daftar pertanyaan kuisioner yang telah disusun sebelumnya. Sedangkan data sekunder diperoleh dari instansi, Departemen/ dinas, dan pustaka yang terkait dengan permasalahan yang diteliti serta dari laporan hasil penelitian dari pihak-pihak yang terkait.

Metode analisis data yang digunakan dalam penelitian ini adalah analisis deskriptif dan kuantitatif. Data yang dikumpulkan diolah secara tabulasi dan dilanjutkan dengan analisis Linier Programming dengan menggunakan metode simpleks. Hasil analisis yang dilakukan dengan metode simpleks ini akan diperoleh rencana optimal atau keuntungan maksimal apabila nilai $\mathrm{Zj}-\mathrm{Cj}$ yang terdapat pada tabel simpleks sudah tidak ada lagi yang bernilai negatif.

Pada penelitian ini yang digunakan sebagai faktor pembatas adalah luas lahan, tenaga kerja dan modal. Penggunaan lahan untuk tiap cabang usahatani didasarkan pada musim tanam, begitu juga dengan modal yang digunakan. Sedangkan penggunaan tenaga kerja yang dicurahkan untuk setiap kegiatan usahatani dihitung dalam setiap 2 bulan kegiatan selama setahun. Setiap bentuk kegiatan usahatani dihitung berdasarkan lamanya hari kerja setara pria dengan satuan HOK. Dengan membandingkan hasil analisis dengan keadaan penggunaan faktor produksi yang dilakukan petani akan dapat diketahui apakah petani tersebut telah menggunakan 
faktor produksi tersebut secara optimal. Untuk memperoleh solusi rancangan linier optimasi penggunaan faktor produksi dirumuskan secara matematik sebagai berikut.

Model Matematika :

Fungsi tujuan :

Maksimumkan $\mathrm{Z}=\mathrm{C}_{1} \mathrm{X}_{1}+\mathrm{C}_{2} \mathrm{X}_{2+} \mathrm{C}_{3} \mathrm{X}_{3}$

Fungsi Kendala :

1. $X_{1}+X_{2}+X_{3} \leq b_{1}$

2. $a_{12} X_{1}+a_{22} X_{2}+a_{32} X_{3} \leq b_{2}$

3. $a_{13} X_{1}+a_{23} X_{2}+a_{33} X_{3} \leq b_{3}$

Dimana : $X_{1}, X_{2}, X_{3} \geq 0$

$\mathrm{Z}$ : Fungsi tujuan yang memaksimumkan pendapatan petani

$\mathrm{X}_{1}$ : Luas usahatani padi (Ha)

$\mathrm{X}_{2}$ : Luas Usahatani jagung (Ha)

$\mathrm{X}_{3}$ : Luas Usahatani Kedelai (Ha)

$\mathrm{b}_{1}$ : Kendala Luas Lahan (Ha)

$\mathrm{b}_{2}$ : Kendala tenaga kerja (HOK)

$b_{3}$ : Kendala modal (Rupiah)

$\mathrm{a}_{1}$ : Koefisien penggunaan TK untuk padi per Ha

$\mathrm{a}_{2}$ : Koefisien penggunaan TK untuk jagung per $\mathrm{Ha}$

$a_{3}:$ Koefisien penggunaan TK untuk kedelai per Ha

\section{HASIL DAN PEMBAHASAN}

\section{Identitas Petani Sampel}

Identitas petani dalam penelitian ini dibatasi pada beberapa karakteristik yang diperkirakan dapat mempengaruhi kemampuan petani dalam berusahatani. Adapun karakteristik yang dimaksud adalah umur petani, tingkat pendidikan, jumlah anggota keluarga dan pengalaman dalam berusahatani tanaman padi sawah, jagung dan kedelai.

Tabel 2. Identitas Petani Sampel di Daerah Penelitian.

\begin{tabular}{|c|c|c|c|}
\hline Identitas Petani & Rata-rata & $\begin{array}{c}\text { Freku } \\
\text { ensi }\end{array}$ & $\begin{array}{c}\text { Persen } \\
\text { tase }\end{array}$ \\
\hline $\begin{array}{l}\text { Umur Petani } \\
\text { (Tahun) }\end{array}$ & $36-41$ & 15 & 23.25 \\
\hline $\begin{array}{l}\text { Jumlah Anggota } \\
\text { Keluarga } \\
\text { (Orang) }\end{array}$ & $3-4$ & 26 & 78,75 \\
\hline $\begin{array}{l}\text { Tingkat } \\
\text { Pendidikan }\end{array}$ & SD & 27 & 45.25 \\
\hline $\begin{array}{l}\text { Pengalaman } \\
\text { Berusahatani } \\
\text { (Tahun) }\end{array}$ & $8-11$ & 27 & 38 \\
\hline
\end{tabular}

Berdasarkan Tabel 2 diketahui bahwa rata-rata petani di daerah penelitian berada pada rentang 35-41 tahun dengan presentase 23,25\% Hal ini menunjukkan bahwa rata-rata berada pada usia produktif. Umur memegang peranan penting dalam berusahatani. Soeharjo dan Patong (1973) menyatakan bahwa umur adalah identitas yang dapat mempengaruhi pola pikir seseorang, semakin tua umur seseorang akan semakin matang cara berfikirnya untuk mengatasi masalah.

Rata-rata jumlah anggota keluarga petani adalah 3-4 orang, petani dengan jumlah tanggungan lebih besar maka kebutuhan keluarga akan lebih besar pula. Hernanto (1998), mengatakan bahwa besarnya anggota keluarga akan berpengaruh dalam kegiatan usahataninya, petani yang memiliki keluarga yang besar akan memakai anggota keluarga sebagai tenaga kerja dalam kegiatan usahatani sehingga tidak membayar biaya upah.

Tingkat pendidikan, menurut Hernanto (1998), keterbatasan tingkat pendidikan akan mempengaruhi cara berfikir, menerima, ataupun menolak hal-hal baru. Tingkat pendidikan juga akan berpengaruh terhadap kecerdasan dalam hal menerima sesuatu yang baru atau penemuan baru, hal ini dikarenakan pendidikan bertujuan merubah sikap dan tingkah laku manusia. Rata-rata tingkat pendidikan petani adalah SD.Keadaan tingkat pendidikan yang relatif rendah memperlihatkan bahwa dalam pengelolaan usaha pertanian lebih banyak menitik beratkan pada teknis atau Technical Skill dari pada keahlian konsep atau Conceptual Skill.

Pengalaman seseorang dapat dijadikan tolak ukur untuk pengembangan di masa yang akan datang. Pengalaman yang diperoleh dalam berusahatani dapat mempengaruhi kemampuan dalam mengelola maupun mengambil keputusan bagi pengelolaan usahataninya. Menurut Hernanto (1998), makin tinggi pendidikan dan pengalaman petani maka akan berhati-hati serta menghitung kemungkinan resiko yang akan dihadapi. Rata-rata pengalaman berusahatani petani di daerah penelitian cukup lama yaitu 8-11 tahun, lamanya pengalamam berusahatani ini juga akan berpengaruh terhadap pola pikir dalam pengambilan keputusan. 


\section{Optimasi Usahatani}

\section{Model optimasi usahatani dengan pendekatan Linear Programing}

Dalam penelitian ini, ada 3 (tiga) model pola tanam yang akan dioptimasikan. Maksud dari optimasi ini adalah untuk mengetahui komoditi dan pola tanam mana yang optimal atau sebaiknya diusahakan dalam upaya memaksimumkan pendapatan petani dari usahatani padi, jagung dan kedelai, dengan memperhatikan keterbatasan dari faktor produksi lahan, tenaga kerja dan modal yang tersedia.

\section{Luas lahan dan pola tanam optimal}

Melalui hasil perhitungan metode simpel diperoleh nilai optimal dari luas lahan dan pola tanam padi, jagung dan kedelai. Total luas lahan optimal pola tanam model I adalah 4,8 ha, dimana lahan optimal padi sawah adalah 3,3 ha, jagung 1,5 ha, sedangkan kedelai 0 ha yang artinya kedelai tidak optimal untuk diusahakan. Total luas optimal pola tanam ini sama dengan luas lahan sebelumnya dan sesuai juga dengan luas yang tersedia dalam satu tahun yaitu sebesar 4,8ha. Sehingga dengan pola tanam optimal ini tidak ada lahan yang tersisa.

Nilai shadow price dari kendala lahan tidak tersisa (habis dipakai) adalah positif. Dari hasil perhitungan optimasi shadow price, kendala lahan pola tanam model I ini adalah 2.875.395,75, artinya setiap penambahan 1 ha lahan maka dapat meningkatkan pendapatan optimal petani sebesar Rp. 2.875.395.75,00. Pada pola tanam optimal model II, total luas lahan optimal adalah 4,1 ha dengan komoditi padi adalah 1,6 ha dan jagung 2,5 ha. Sementara kedelai juga dinilai tidak layak untuk diusahakan karena luas optimalnya adalah 0 ha. Total luas optimal ini lebih kecil dari total luas usahatani sebelumnya. Ini karena luas usahatani jagung yang optimal yang dapat diusahakan pada MT II dan III adalah sebesar 2,5 ha yang lebih kecil dari potenasi lahan yang tersedia pada musim tanam tersebut yaitu sebesar 3,2 ha. Sehingga dengan pola tanam model II potensi luas tersedia di MT II dan MT III masih tersisa sebesar 0,7 ha.

Nilai shadow price pada kendala yang tersisa adalah nol. Sehingga dari hasil perhitungan optimasi dapat dilihat pada pola tanam model II shadow price kendala lahan di MT II dan III adalah 0 artinya penambahan lahan pada pola ini tidak akan meningkatkan pendapatan optimal petani. Sedangkan di MT I yang diusahakan padi adalah positif yaitu sebesar 1.160.126,125 artinya setiap penambahan lahan padi seluas 1 ha pada MT I maka akan meningkatkan pendapatan optimal sebesar Rp. 1.160.126,75.

Apabila pola tanam optimal model II ingin dikembangkan maka perlu dilakukan penataan ulang penanaman padi dan jagung. Komoditi padi diusahakan tetap pada MT I dengan luas 1,6 ha yang sama dengan luas sebelumnya, dan komoditi jagung diusahakan 2 kali dalam satu tahun yaitu di MT II dan MT III, masing-masing bisa ditentukan luasnya dengan tidak melebihi total batasan lahan yang optimal yaitu seluas 2,5 ha. Sedangkan kedelai tidak diusahakan karena dinilai tidak layak.

Selanjutnya pada pola tanam model III, total luas lahan optimal adalah 3,2 ha dengan luas optimal padi dan jagung masing-masing 1,6 ha, sedangkan kedelai juga tetap tidak layak diusahakan dimana luas optimal kedelai adalah 0 ha. Pola tanam model III ini merupakan pola tanam yang dilaksanakan petani. Bila pola tanam optimal model III ini ingin dikembangkan maka petani tidak perlu mengusahakan komoditi kedelai.

Total luas optimal pola tanam model III ini lebih kecil dari potensi luas tersedia yang dapat dikembangkan pada masing-masing musim tanam. MT I dan MT II layak untuk ditanam padi dan jagung dengan luas lahan yang sama dengan sebelumnya yaitu masingmasing 1,6 ha . Sedangkan di MT III tidak layak diusahakan kedelai sehingga dengan pola tanam model III potensi luas tersedia masih tersisa sebesar 1,6 ha. Hal ini karena dinilai lahan yang diperuntukan untuk komoditi kedelai tidak perlu diusahakan.Shadow price untuk kendala lahan padi di MT I dan lahan jagung di MT II adalah positif yaitu masingmasing sebesar 3.710.844,25 dan 4.275.901,50. Sedangkan shadow price untuk kendala lahan kedelai di MT III adalah 0

\section{Tenaga kerja optimal}

Penggunaan tenaga kerja optimal yang paling besar terdapat pada pola tanam model I yaitu sebesar 180 HOK, kemudiaan diikuti oleh pola tanam model II dan III. Dari tenaga kerja yang 
tersedia sebesar 300 HOK setahun, ternyata tidak semua tenaga tersebut digunakan dalam mengusahakan pola tanam optimal . Semakin banyak tenaga kerja optimal yang digunakan maka semakin sedikit tenaga kerja tersedia yang tersisa.Nilai Shadow price dari kendala tenaga kerja yang tersisa pada masing-masing model adalah nol yang berarti penambahan satu HOK tenaga kerja tidak meningkatkan pendapatan optimal dari usahatani optimal tersebut. Dengan demikian dapat dinyatakan bahwa tenaga kerja tersedia pada daerah penelitian ini belum menjadi faktor pembatas dalam mengusahakan usahatani padi, jagung dan kedelai.

Tenaga kerja yang tersisa ini dapat dijadikan sebagai faktor produksi bagi petani untuk mengusahakan usaha lain, tetapi diharapkan usaha yang akan dijalankan tidak mengganggu penggunaan faktor produksi lainnya, terutama dalam penggunaan modal usahatani. Karena pada umumnya masalah pembiayaaan usahatani merupakan masalah klasik yang sering dihadapi petani di negara kita. Mengenai gambaran modal usahahatani optimal pada model pola tanam di daerah penelitian akan diuraikan di bawah ini.

\section{Modal optimal}

Penggunaan modal yang optimal dari pola tanam model III adalah paling terkecil dibandingkan dengan model I dan II. Jumlah optimal yang digunakan juga lebih kecil dari ketersediaan modal yang dimiliki petani. Kondisi tersebut membuat hasil optimasi tersisa modal sebesar Rp 8.834.305,00. Shadow price kendala modal yang tersisa penggunaannya ini adalah nol, sehingga setiap penambahan satu satuan rupiah modal pada pola tanam model III tidak meningkatkan pendapatan optimal usahatani.

Penggunaan modal optimal dari pola tanam model I dan II adalah sama besarnya dan jumlah penggunaanya juga sesuai dengan ketersediaan modal yang ada, sehingga tidak terdapat sisa modal pada kedua pola tanam ini. Ini berarti bahwa pada pola tanam optimal model I dan II modal menjadi pembatas bagi petani untuk mengusahakan usahataninya. Shadow price dari modal yang tidak tersisa atau habis terpakai pada pola tanam model I dan II ini adalah positif yang masing-masing adalah 0.143510 dari kendala modal untuk pola tanam model I dan 0.438153 kendala modal untuk pola tanam model II, yang artinya setiap penambahan $\mathrm{Rp} \quad 1.000 .000$ modal akan meningkatkan pendapatan sebesar Rp 143.510 pada usahatani dengan pola tanam model I dan Rp 438.153 pada pola tanam model II.

\section{Pendapatan optimal}

Pendapatan yang paling optimal dari 3 (tiga) model pola tanam yang mungkin dapat dikembangkan di daerah penelitian adalah pola tanam model I. Kemudian dapat diikuti oleh pengusahaan dengan pola tanam model II dan III. Namun untuk pola tanam III perubahan pendapatan optimal mengalami penurunan sebesar 9,9\% dari pendapatan petani semula yang telah diusahakan petani. Berbeda dengan pola tanam model I dan II, pendapatan optimal yang dapat diperoleh petani akan naik sebesar $31,50 \%$ untuk model I dan $17,40 \%$ untuk model II.

Pola tanam model III yang diusahakan petani ternyata lebih optimal daripada pendapatan yang dioptimasikan. Hal ini diperkirakan karena nilai pendapatan dari tanaman kedelai per ha kecil sekali dibandingkan dengan padi dan jagung, sementara batas luas lahan yang tersedia dalam model III di samakan antara ke 3 komoditi tersebut yaitu sama-sama 1,6 ha. Sehingga untuk memperluas tanaman padi dan jagung yang memiliki potensi untuk dikembangkan terpaksa dibatasi hanya 1,6 ha. Sedangkan untuk mengusahakan kedelai, potensi pendapatannya kecil sekali dibandingkan dengan padi dan jagung, sehingga kedelai tidak masuk sebagai solusi yang fisibel. Dan ini malah membuat pendapatan optimal lebih kecil dari pendapatan yang diusahakan petani.

\section{Analisis Sensitivitas}

Analisis sensitivitas digunakan untuk mengetahui sampai seberapa jauh batas-batas perubahan masih dimungkinkan sehingga hasil optimasi ini masih berlaku dan dapat dipakai sebagai alat perencanaan usahatani pajale (padi, jagung dan kedelai).

\section{Sensitivitas terhadap perubahan tingkat pendapatan per ha.}

Bertujuan untuk mengetahui batas bawah dan batas atas (allowable increase and allowable decrease) perubahan pendapatan yang 
diperkenankan, sehinggga hasil optimasi tidak berubah atau dapat dipertahankan. Pada pola tanam model I, perubahan batas atas pendapatan dari usahatani padi adalah tidak terbatas dan perubahan batas bawah pendapatannya adalah Rp. 1,160,126,00. Ini artinya dengan asumsi pendapatan dari usahatani jagung dan kedelai tetap maka apabila pendapatan padi semula ditingkatkan sampai tidak terbatas atau diturunkan dengan perubahan sampai Rp. 1.160.126,00 maka tidak akan merubah hasil optimasi. Dalam hal ini, padi dan jagung tetap optimal untuk diusahakan pada pola tanam tersebut. Namun apabila perubahan pendapatan padi diluar batas atas atau maksimum dan turun diluar batas bawah atau minimum maka hasil optimasi akan berubah. Hasil optimasi dengan menggunakan linear programing ini masih dapat dipertimbangkan untuk pengembangan komoditi padi, jagung dan kedelai di daerah penelitian.

\section{Sensitivitas terhadap perubahan tingkat kendala.}

Bertujuan untuk mengetahui batas atas dan batas bawah perubahan dari kendala/pembatas yang tidak akan merubah nilai shadow price, yang artinya apabila kendala lahan, tenaga kerja dan modal berubah sebesar satu satuan, maka pendapatan optimal akan berubah secara tetap sebesar nilai shadow price.Perubahan batas atas kendala lahan pada pola tanam model I adalah $0,99 \approx 1$ ha dan batas bawahnya 1,34 ha. Ini artinya dengan menganggap kendala lain yaitu tenaga kerja dan modal pada pola tanam ini tetap, apabila lahan yang tersedia ditingkatkan sampai batas atas perubahan sebesar 1 ha dan diturunkan sampai batas bawah perubahannya 1,34 ha dari luas lahan semula maka nilai shadow price lahan terhadap kenaikan pendapatan adalah tetap. Nilai shadow price lahan pada pola tanam optimal model I telah diketahui adalah Rp. 2.875.395.75,00. Bila lahan pada pola ini dinaikan sebesar nilai yang berada pada batas ambang atas dan bawah maka pendapatan optimal akan naik secara tetap sebesar nilai shadow price tersebut. Hal yang sama dapat diartikan untuk sensitivitas kendala lahan, kerja dan modal pada pola tanam lainnya .

Analisis sensitivitas bagi kendala yang tidak habis terpakai (tersisa) memiliki batas atas yang tidak terbatas, tetapi batas bawah bernilai positif. Hal ini berarti berapun jumlah kendala itu dinaikan maka nilai shadow price nya adalah tetap nol yang tidak akan mempengaruhi meningkatnya pendapatan optimal. Sebaliknya untuk mempertahankan shadow price tetap nol maka penurunan kendala ini harus sampai batas bawah nilai positifnya. Di luar batas ambang bawah ini maka nilai shadow price bisa berubah atau tidak nol lagi.

\section{KESIMPULAN DAN SARAN}

Berdasarkan hasil penelitian dapat ditarik kesimpulan bahwa : 1) Terdapat 3 (tiga) pola tanam yang potensi untuk dioptimalkan dengan tetap memperhatikan kendala yang sama dari ketersediaan tenaga kerja dan modal dimana pola I; padi, jagung dan kedelai potensi untuk diusahakan pada MT I, MT II dan MT III dari luas lahan tersedia dengan indeks pertanaman $300 \%$ seluas 4,8 ha, pola II; padi diusahakan pada MT I seluas maksimum 1,6 ha. Sedangkan jagung dan kedelaipotensi diusahakan pada MT II dan III dari luas lahan yang tersedia dengan indeks pertanaman $200 \%$ seluas 3,2 ha.- Pola tanam III; padi diusahakan hanya di MT I, jagung di MT II dan kedelai di MT III, dengan luas masing-masing maksimum sebesar 1,6 ha. 2) Dari ketiga pola tanam yang dioptimasi, komoditi padi dan jagung dinilai optimal untuk dikembangkan oleh petani di daerah penelitian, Besarnya luas optimal padi dan jagung pada pola tanam I adalah padi 3,3 ha dan jagung 1,5 ha. Pada pola tanam II, luas optimal padi adalah 1,6ha dan jagung 2,5 ha. Sedangkan pada pola tanam III luas optimal padi dan jagung adalah sama yaitu seluas 1,6 ha.3) Dari ketiga pola tanam tersebut yang paling optimal adalah pola tanam I, kemudian diikuti dengan pola tanam model II dan III. Pola tanam III sebenarnya merupakan pola tanam yang dilaksanakan petani. Dari hasil optimasi ternyata pola tanam yang dilaksanakan petani ini sudah optimal, tetapi tingkat optimalnya masih lebih rendah dari pola tanam I dan pola tanam II.

\section{DAFTAR PUSTAKA}

Badan Balitbang Pertanian. 2015. Pedoman IP Padi Sawah. Denpasar: BPTP Bali. 
Badan Pusat Statistik. 2015. Statistik Pertanian Padi Palawija Kabupaten Muaro Jambi tahun 2015. Muaro Jambi: BPS Kabupaten Jambi.

Balai Penyuluh Pertanian Kecamatan Kumpeh. 2016. Program BPP Kecamatan Kumpeh. Kabupaten Muaro Jambi.

Daniel, M. 2009. Pengantar Ekonomi Pertanian. Jakarta: Bumi Aksara.

Deptan. 2016. Pedoman Umum Proyek Ketahanan Pangan TA. 2016. Jakarta.

Hernanto, F. 1996. Ilmu Usahatani. Jakarta: Penebar Swadaya.

Mubyarto. 1995. Pengantar Ekonomi Pertanian. Jakarta: LP3ES.

Nazir, M.2005. Metode Penelitian. Jakarta: PT. Ghalia.
Riduan. 2007. Rumus dan Data Dalam aplikasi Statistika Untuk Penelitian. Bandung: Alfabeta.

Rukmana, R. H. 1997. Usahatani Jagung. Yogyakarta: Kanisius.

Sugiono, P.D. 2014. Metode Penelitian Kuantitatif, Kualitatif Dan $R \& D$. Bandung: Alfabeta.

Suratiyah, K. 2011. Ilmu Usahatani. Yogyakarta: Penebar Swadaya.

Soeharjo, A. dan Dahlan, P. 1973. Sendi-Sendi Pokok Usahatani, Departemen IlmuIlmu Sosial Ekonomi Pertanian. Bogor: Fakultas Pertanian, Institut Pertanian Bogor. 